\title{
Competition Effects and Productivity in Oat-Forage Legume Relay Intercropping Systems under Organic Farming Conditions
}

\author{
Viktorija Gecaitè $^{1, *}$, Aušra Arlauskiene ${ }^{1}$ and Jurgita Cesevičienè ${ }^{2}$ (I) \\ 1 Joniškèlis Experimental Station, Lithuanian Research Centre for Agriculture and Forestry, Pasvalys Distr., \\ 39301 Joniškèlis, Lithuania; ausra.arlauskiene@lammc.lt \\ 2 Institute of Agriculture, Lithuanian Research Centre for Agriculture and Forestry, Instituto 1, Kèdainiai Distr., \\ 58344 Akademija, Lithuania; jurgita.ceseviciene@lammc.lt \\ * Correspondence: viktorija.gecaite@lammc.lt; Tel.: +370-62851350
}

check for updates

Citation: Gecaitè, V.; Arlauskienè, A.; Cesevičienè, J. Competition Effects and Productivity in Oat-Forage

Legume Relay Intercropping Systems under Organic Farming Conditions. Agriculture 2021, 11, 99. https:// doi.org/10.3390/agriculture11020099

Academic Editors: Claudia Di Bene, Rosa Francaviglia, Roberta Farina, Jorge Álvaro-Fuentes and Raúl Zornoza

Received: 11 December 2020

Accepted: 20 January 2021

Published: 25 January 2021

Publisher's Note: MDPI stays neutral with regard to jurisdictional claims in published maps and institutional affiliations.

Copyright: (c) 2021 by the authors. Licensee MDPI, Basel, Switzerland. This article is an open access article distributed under the terms and conditions of the Creative Commons Attribution (CC BY) license (https:// creativecommons.org/licenses/by/ $4.0 /)$.

\begin{abstract}
Cereal-legume intercropping is important in many low-input agricultural systems. Interactions between combinations of different plant species vary widely. Field experiments were conducted to determine yield formation regularities and plant competition effects of oat (Avena sativa L.)-black medick (Medicago lupulina L.), oat-white clover (Trifolium repens L.), and oat-Egyptian clover (T. alexandrinum L.) under organic farming conditions. Oats and forage legumes were grown in mono- and intercrops. Aboveground dry matter (DM) measured at flowering, development of fruit and ripened grain, productivity indicators, oat grain yield and nutrient content were established. The results showed that oats dominated in the intercropping systems. Oat competitive performance $\left(\mathrm{CP}_{\mathrm{O}}\right)$, which is characterized by forage legumes aboveground mass reduction compared to monocrops, were 91.4-98.9. As the oats ripened, its competitiveness tendency to declined. In oat-forage legume intercropping systems, the mass of weeds was significantly lower compared to the legume monocrops. Oats and forage legumes competed for $\mathrm{P}$, but $\mathrm{N}$ and $\mathrm{K}$ accumulation in biomass was not significantly affected. We concluded that, in relay intercrop, under favourable conditions, the forage legumes easily adapted to the growth rhythm and intensity of oats and does not adverse effect on their grain yield.
\end{abstract}

Keywords: aboveground mass; black medick; Egyptian clover; grain yield; nutrients; white clover

\section{Introduction}

Enhancing crop diversity and growing legumes are increasingly recognised as a crucial lever for sustainable agroecological development [1]. This is the basis of organic arable farms. The choice of plant species in a stockless farm is small and the use of forage legumes is limited. Intercropping is important in many subsistence or low-input/resourcelimited agricultural systems [2]. Intercropping, the simultaneous growth of more than one crop species or genotype in the same field [3], is the practical application of basic ecological principles [2]. Intercropping effects consist of competition (niche differentiation, resource sharing and weed control), diversity (insect and disease control), facilitation (physical support, nitrogen fixation and excretion of allelochemicals and modification of the rhizosphere) and associated diversity (habitats for natural predators, litter diversity and enhanced soil microbial diversity) [4]. Strip, mixed and relay intercropping can be used to increase crop yields through resource partitioning and facilitation. Relay intercropping involves the staggered planting of two or more crops together in a way whereby only parts of their life cycles overlap [5]. Farmers often intercrop forage legumes into winter or spring cereals as a way to increase crop diversity and increase labile nitrogen pools [6]. This intercropping system works particularly well because of the different phenologies of the two crops, which minimises light competition, as well as differences 
in nutrient acquisition [7]. Intercropping can allow better use of subsoil resources, and thereby decrease the need for resource input and help avoid nutrient losses [8,9]. Moreover, one crop can provide resources for the other one with a positive interspecific interaction, which is at the basis of facilitation processes [10]. Intercropping systems improve soil temperature and moisture regulation; erosion, nutrient run-off and leaching are reduced; weeds are controlled insect and disease development cycles are interrupted and soil organic matter content is improved with recycled nutrients being made available to subsequent crops [11,12].

There is competition between the plants in the intercropping system. It is one of many ecological processes shaping the composition, dynamics and productivity of the plant community [1]. Mainly, plants compete for soil resources and light. These interactions affect plant density and plant development rhythm as well as productivity and fertility [13] Plant competition in spring cereal-forage legume intercropping systems can be regulated by proper selection of plant species [8], optimal plant seed rate and sowing time and methods [14]. Oat is grown in non-fertile soil regions and also in crop production farms globally. Oats are widely used cereal grains grown for its seed and are increasingly used every year. The growing population of health-conscious people is forcing oats manufacturers to increase growing demand. Therefore, the rising demand for oats has led to improve and increase their research. Relay intercropping systems are an important cropping strategy for sustainable agriculture in many countries as they create benefits in terms of better utilisation of soil resources, weed control and yield diversification. In Lithuania, combinations of legumes and non-legumes are a widely spread practice and several studies have been published on the subject, e.g., pea-spring cereal intercropping systems $[15,16]$.

Red (T. pratense L.) and white clover are most often under sown with cereals. In order to increase the services provided by plants and their applicability in greening technologies (cover and catch crops, mixer, strip, relay intercropping systems, etc.), other types of forage legumes have been studied and adapted. Egyptian is a high-yielding, nutritious, coolseason forage crop that can grow on a wide range of soils, though it prefers fertile $[17,18]$. Egyptian clover can withstand some drought and short periods of waterlogging [19]. This type of clover has a short growing season, therefore, there is a wider range for its application compared to perennial clover.

Black medick is a self-seeding legume that has potential for pasture, green manure, cover cropping, intercropping, and phytoremediation throughout temperate and subtropical regions of the world. It is grown both for agronomic and environmental benefits [20]. More recently, black medick has been recognised for its heavy metal tolerance [21]. Its root leachates provide selective allelopathic suppression of weed growth [22]. The use of a self-seeding legume may be a solution to avoid the cost of seeding cover crops annually [23]. However, black medick can also spread like a weed [24]. Nitrogen fertiliser suppresses medick growth, so black medick cover would be beneficial only in low $\mathrm{N}$ or organic farming systems [25]. The aim of this study was to determine yield formation regularities and the yield and plant competition effects in different relay intercropping systems, namely, oat-black medic, oat-white clover and oat-Egyptian clover in clay loam Cambisol under organic farming conditions.

\section{Material and Methods}

\subsection{Experimental Site}

Field experiments were conducted at the Joniškèlis Experimental Station of the Lithuanian Research Centre for Agriculture and Forestry in the northern part of Central Lithuania's lowland. The soil of the experimental site is Endocalcari Endohypogleyic Cambisol, whose texture is clay loam on silty clay with deeper lying sandy loam. The topsoil $(0-25 \mathrm{~cm})$ is close to neutral ( $\mathrm{pH}$ 6.1), medium in phosphorus $\left(\mathrm{P}_{2} \mathrm{O}_{5} 146 \mathrm{mg} \mathrm{kg}^{-1}\right)$, high in potassium $\left(\mathrm{K}_{2} \mathrm{O} 276 \mathrm{mg} \mathrm{kg}^{-1}\right)$ and moderate in humus $(2.54 \%)$. 
During plant development and growth in 2018, April was the wettest, however a similar amount of rainfall fell in May, July and August (Figure 1a). April and May were quite abundant in humidity, heat and sunlight which led to good plant development in the first stages of oat growth. In contrast, precipitation was considerably lesser compared to the standard climate normal (SCN) average data resulted in slower plant development. The year 2019 was slightly wetter and the monthly distribution of precipitation was significantly more even than 2018. In 2019, April was distinguished by a very low rainfall (Figure 1b). The drought, which began in the first 10-day period of April and extended to the end of May. A more abundant amount of precipitation fell only in the third 10-day period of May after which more intensive growth of the aboveground mass of plants began. June was unusually hot, and July was exceptionally wet.

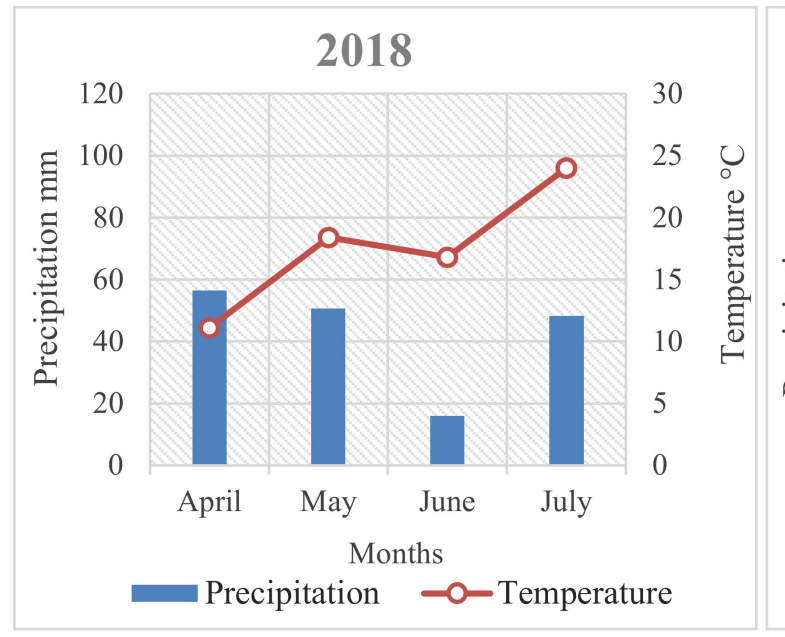

(a)

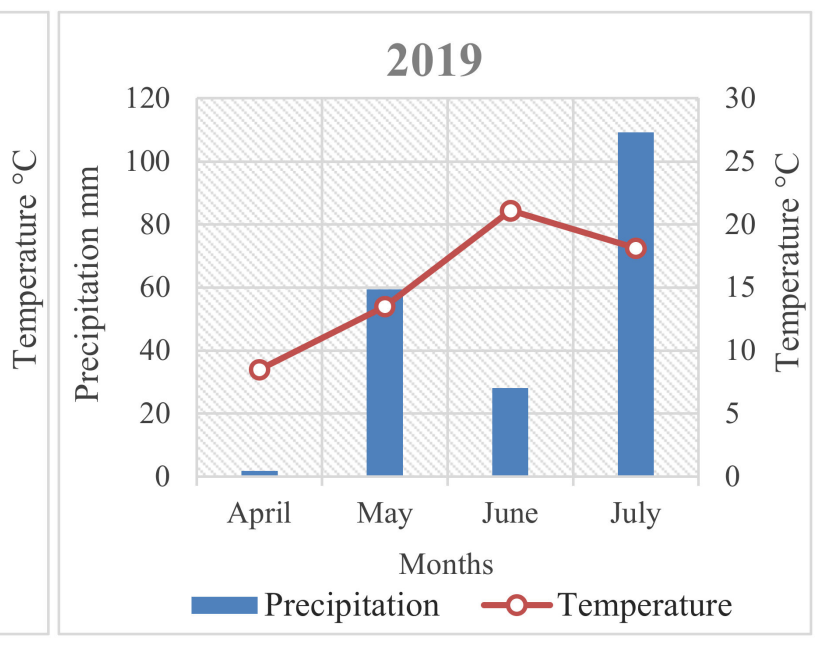

(b)

Figure 1. Distribution of monthly (April-July) precipitation and average temperature over 2018 (a) and 2019 (b) at Joniškèlis Experimental Station of the Lithuanian Research Centre for Agriculture and Forestry.

\subsection{Experimental Design, Plant Sampling and Analysis}

Two analogous field experiments were established and carried out in 2018 and 2019 in separate areas of the same field. The following experimental design was used for monocrops and relay intercropping systems: (1) Oat (O; cultivar 'Migla DS'); (2) black medick (BM; cultivar 'Arka 133 DS')); (3) white clover (WC; cultivar 'Nemuniai'); (4) Egyptian clover (EC; cultivar 'Cleopatra'); (5) oat-black medick (O+BM); (6) oat-white clover $(\mathrm{O}+\mathrm{WC})$; (7) oat-Egyptian clover (O+EC). The oat was sown on 23 April 2018 and 16 April 2019 at a seeding rate of 450 seeds $\mathrm{m}^{-2}$ using a drill at a $3 \mathrm{~cm}$ depth. The forage legume species were intercropped in oats on 25 April 2018 and 16 April 2019 at a seed rate of 50 seeds $\mathrm{m}^{-2}$. The forage legume seeds were sown at a $2 \mathrm{~cm}$ depth using a drill. The experiment was laid out in a one-factor randomised complete block design in four replications and individual plot size was $6 \times 20 \mathrm{~m}$. Crops were cultivated according to organic management practices.

At full germination, the oats and forage legumes plants were accounted in $0.25 \mathrm{~m}^{2}$ plots, in four places per plot. In order to evaluate the growth patterns, of plants, the aboveground mass of oat, forage legumes and weeds were determined when oats reached the flowering (BBCH 61-63), grain development (BBCH 71-73), and ripened grain (BBCH 87-89) growth stages. Sampling of aboveground biomass occurred at four randomly chosen squares of $0.25 \mathrm{~m}^{2}$ in each plot, which were cut to ground level and weighed on each date. The aboveground dry matter (DM) mass was determined (dried to a constant weight at $105^{\circ} \mathrm{C}$ in a forced-air oven), of oat, forage legumes, weeds and subsample values from each plot were averaged. 
The oat crop was harvested, at complete maturity stage (plot size $2.3 \times 18.0 \mathrm{~m}$ ) with a small combine harvester on 2 August 2018, and 4 August 2019. Before combining, 25 oat plants per plot were collected to determine the number of panicles per unit area (panicle $\mathrm{m}^{-2}$ ), number of grains per panicle (grain per panicle) and grain weight per panicle $(\mathrm{g})$ of oats. Grain samples $(1 \mathrm{~kg})$ were taken from each plot for the determination of 1000-grain weight (TGW) and grain DM content. Oat grain and straw yield were measured by weighing. The grain yield was converted to standard moisture (14\%) and straw to DM. Competitive performance $(\mathrm{CP})$ was expressed as the percent reduction in aboveground dry mass as follows: $\mathrm{CP}_{\mathrm{O}}=\left[\left(\mathrm{P}_{\mathrm{fl} / \mathrm{s}}-\mathrm{P}_{\mathrm{fl} / \mathrm{i}}\right) / \mathrm{P}_{\mathrm{fl} / \mathrm{s}}\right] \times 100$; where CPo is the relative competitive ability of the oat; $\mathrm{P}_{\mathrm{fl} / \mathrm{s}}$ is the dry mass of the forage legume grown alone (control) and $\mathrm{P}_{\mathrm{fl} / \mathrm{i}}$ is the mass of the forage legume grown in intercrop.

Oat grain and forage legume aboveground mass samples collected at the oat ripened grain stage were dried, milled and analysed for nitrogen $(\mathrm{N})$, phosphorus $(\mathrm{P})$ and potassium (K) content. The concentration was evaluated in the sulphuric acid digestates. Plant samples for $\mathrm{N}$ determination were analysed using the Kjeldahl method with a Kjeltec system 1002 (Foss Tecator, Hoganas, Sweden). The concentration of P was quantified spectrophotometrically by a coloured reaction with ammonium molybdate-vanadate at a wavelength of $430 \mathrm{~nm}$ on a Cary $50 \mathrm{UV}-$ Vis spectrophotometer (Varian Inc., Palo Alto, CA, USA). Respective K concentration was evaluated by atomic absorption spectrometry with an Analyst 200 (Perkin Elmer, Waltham, MA, USA) in accordance with the manufacturer's instructions.

\subsection{Statistical Analysis}

The data were statistically processed using three-factor (year, assessment time and intercrop) for aboveground mass of oat, perennial legume and weed and two-factor (year and intercrop) for grain yield and its component of oat, nutrition concentration and content analysis of variance as well as correlation and regression methods. The data were analysed when the factual Fisher criterion $\left(\mathrm{F}_{\text {fact. }}\right)$ was higher than the theoretical one $\left(\mathrm{F}_{\text {theor. }}\right)$. The significance of differences among the treatment means was estimated at the 0.05 probability levels. Interrelationships among aboveground mass of weeds, forage legumes and oats in monocrops and intercropping systems and among $\mathrm{P}$ in oats grain and legume aboveground mass were estimated. Simple linear regression (SLR) was applied to the data. Statistical analysis of the experimental data was performed using the ANOVA version 3.1 software and STAT_ENG version 1.5 from the programme package SELEKCIJA [26].

\section{Results}

\subsection{Oat and Forage Legume Mass}

Statistical analysis showed that the oat aboveground dry mass yield was significantly $(p<0.01)$ influenced by interaction of year and assessment time (Table 1). The relay intercropping systems did not have any significant effect on the yield of the aboveground oat mass.

The first assessment of the aboveground mass of plants was performed at the beginning of oat flowering and did not differ significantly between the years. The assessment of the aboveground mass of oats during oat grain development revealed that the intensity of the aboveground mass increase of oats was as follows: in 2018 to $18.1 \%$ and in 2019 to $84.2 \%$, compared to the first assessment. In general, a significantly higher aboveground mass of oats was found during grain development in 2019, compared to 2018. The increase in the aboveground mass of oats in relay intercrop has been less pronounced (grain development stage) (Table 2). During the fully ripe stage of oats grain, the changes in their aboveground mass were inconsistent (compared to the grain development stage). In 2019, the DM yield of oat aboveground mass was less compared to the second assessment; however, it was significantly greater on average compared to the corresponding data for 2018. In both years, the yields of oats and oats intercropped with legumes did not differ. 
Table 1. Probability $(p)$ level of factors for aboveground mass of oat, legumes and weeds.

\begin{tabular}{cccc}
\hline \multirow{2}{*}{ Factor/Treatment } & \multicolumn{3}{c}{ Aboveground Mass } \\
\cline { 2 - 4 } & Oat & Legumes & Weeds \\
\hline Year $(\mathrm{Y})$ & $<0.01^{* *}$ & $<0.01^{* *}$ & $<0.01^{* *}$ \\
\hline Assessment time $(\mathrm{Ta})$ & $<0.01^{* *}$ & $<0.01^{* *}$ & $<0.01^{* *}$ \\
\hline Intercrop $(\mathrm{Ic})$ & n.s. & $<0.01^{* *}$ & $<0.01^{* *}$ \\
\hline Interaction $\mathrm{Y} \times \mathrm{Ta}$ & $<0.01^{* *}$ & $<0.01^{* *}$ & $<0.01^{* *}$ \\
\hline Interaction $\mathrm{Y} \times \mathrm{Ic}$ & n.s. & $<0.01^{* *}$ & $<0.01^{* *}$ \\
\hline Interaction Ta $\times$ Ic & n.s. & $<0.01^{* *}$ & $<0.01^{* *}$ \\
\hline Interaction $\mathrm{Y} \times \mathrm{Ta} \times$ Ic & n.s. & $<0.01^{* *}$ \\
\hline **-differences significant at $99^{* *}$ probability levels, n.s.-no significant.
\end{tabular}

Table 2. The variation in the aboveground mass $\left(\mathrm{kg} \mathrm{DM} \mathrm{ha}^{-1}\right)$ of oat during oat reproductive periods in 2018 and 2019.

\begin{tabular}{|c|c|c|c|c|c|c|}
\hline \multirow[b]{3}{*}{ Treatment } & \multicolumn{3}{|c|}{2018} & \multicolumn{3}{|c|}{2019} \\
\hline & \multicolumn{6}{|c|}{ Oat Reproductive Growth Stage (BBCH) } \\
\hline & $\begin{array}{c}\text { Flowering } \\
(61-63)\end{array}$ & $\begin{array}{c}\text { Grain } \\
\text { Development } \\
(71-73)\end{array}$ & $\begin{array}{c}\text { Ripened Grain } \\
\qquad(87-89)\end{array}$ & $\begin{array}{c}\text { Flowering } \\
(61-63)\end{array}$ & $\begin{array}{c}\text { Grain } \\
\text { Development } \\
(71-73)\end{array}$ & $\begin{array}{c}\text { Ripened Grain } \\
(87-89)\end{array}$ \\
\hline $\mathrm{O}$ & 4733 & 5154 & 5714 & 6047 & 10,138 & 8283 \\
\hline $\mathrm{O}+\mathrm{BM}$ & 4681 & 5538 & 5739 & 5612 & 10,514 & 8219 \\
\hline $\mathrm{O}+\mathrm{WC}$ & 4595 & 5842 & 5469 & 5423 & 9930 & 8023 \\
\hline $\mathrm{O}+\mathrm{EC}$ & 5096 & 6023 & 5729 & 5076 & 10,237 & 8048 \\
\hline $\begin{array}{c}\text { Interaction } \\
\mathrm{Y} \times \mathrm{Ic}\end{array}$ & 4776 a & $5639 \mathrm{ab}$ & $5663 \mathrm{~b}$ & $5540 \mathrm{ab}$ & $10,205 \mathrm{c}$ & 8143 c \\
\hline
\end{tabular}

$\mathrm{O}-$ oat monocrop; intercropping systems: $\mathrm{O}+\mathrm{BM}$-oat-black medick, $\mathrm{O}+\mathrm{WC}-$ oat-white clover, $\mathrm{O}+\mathrm{EC} —$ oat-Egyptian clover; means followed by the same letters are not significantly different at $p \leq 0.05$.

The legume aboveground mass yields were influenced by the interaction of all three factors (year, assessment time and treatment, Table 1). During oat flowering, the legume in oats-forage legume intercropping systems did not have any negative effect on the yield of oat aboveground mass in either year (Figure 2). According to the data recorded for 2018, the aboveground mass of legumes was 2.2 times higher on average and that of weeds was $70.6 \%$ lower on average compared to 2019. In both years, the aboveground mass was significantly higher for EC when grown as a monocrop compared to other legumes.

During oat grain development stage, the aboveground mass of the legume monocrop increased most in 2018 (4.1 times) compared to 2019 ( 2.7 times). In both years, the aboveground mass of legumes grown with oats increased similarly (2.7-2.8 times) compared to the first assessment. The mass of different legume species grown in the sole crop and together with oats varied significantly. In terms of the aboveground mass yield, the legumes grown as monocrops ranked as follows: $\mathrm{EC}>\mathrm{WC}>\mathrm{BM}$. The variations between the yields of these species of legumes were significant. The aboveground mass yield of legumes grown as monocrops was greater both years compared to those grown together with oats.

As plants matured, the assimilated materials accumulated in the aboveground mass were transported from leaves to seeds. The oat aboveground mass dried up, exposing the lower crop level. In 2018, during the reproductive period, the mass of perennial legumes increased both in the monocrop and legumes intercropped with oats, with the exception of EC. In 2019, the aboveground mass of legumes increased by 4.7 times on average, this was due to better weather conditions. While assessing different legume species, it was found that the lowest yield of the aboveground mass was that of BM, and the highest was of WC 
and EC. There was no significant difference between the aboveground mass yields of the latter species, either as monocrops or intercrop.

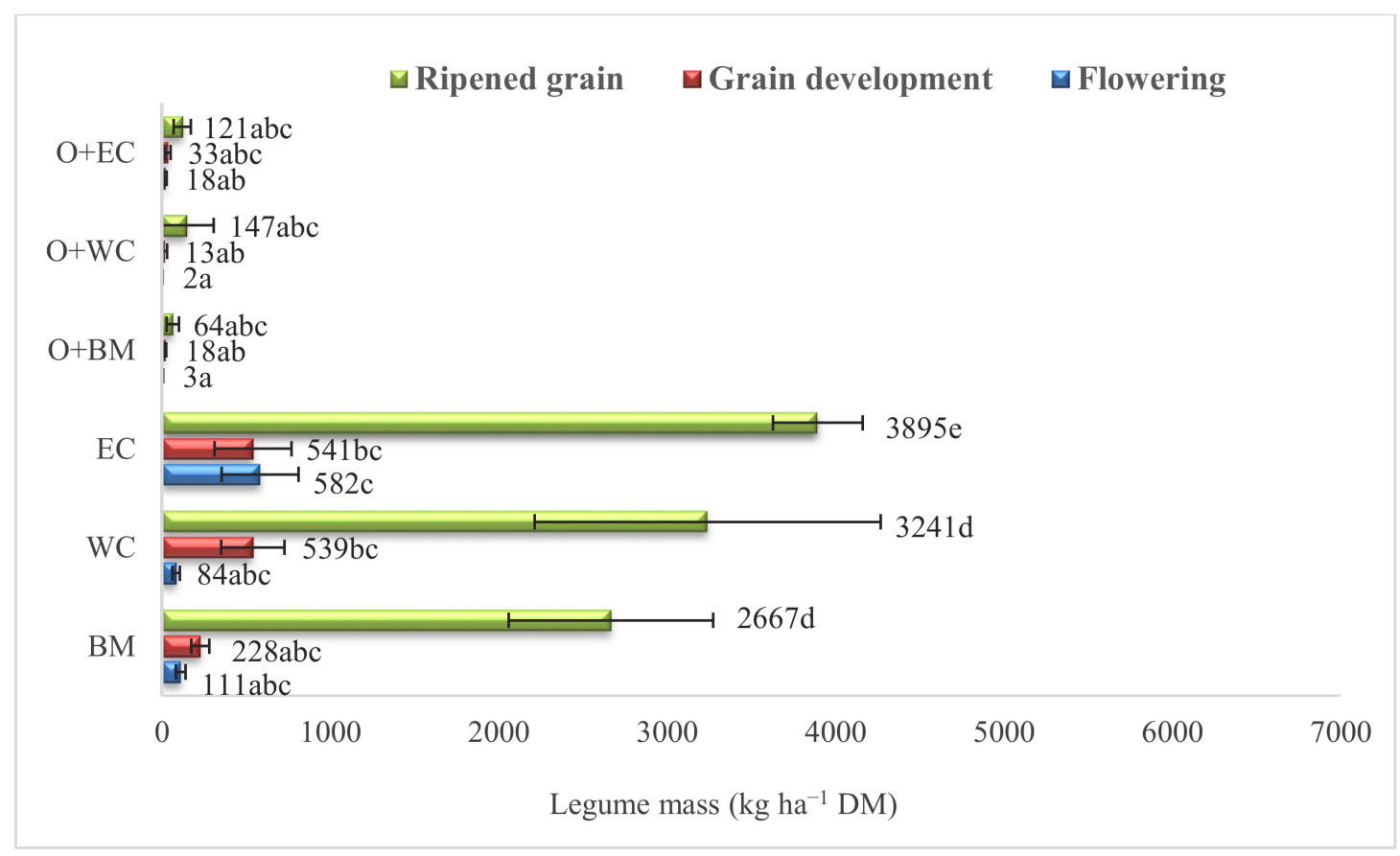

(a)

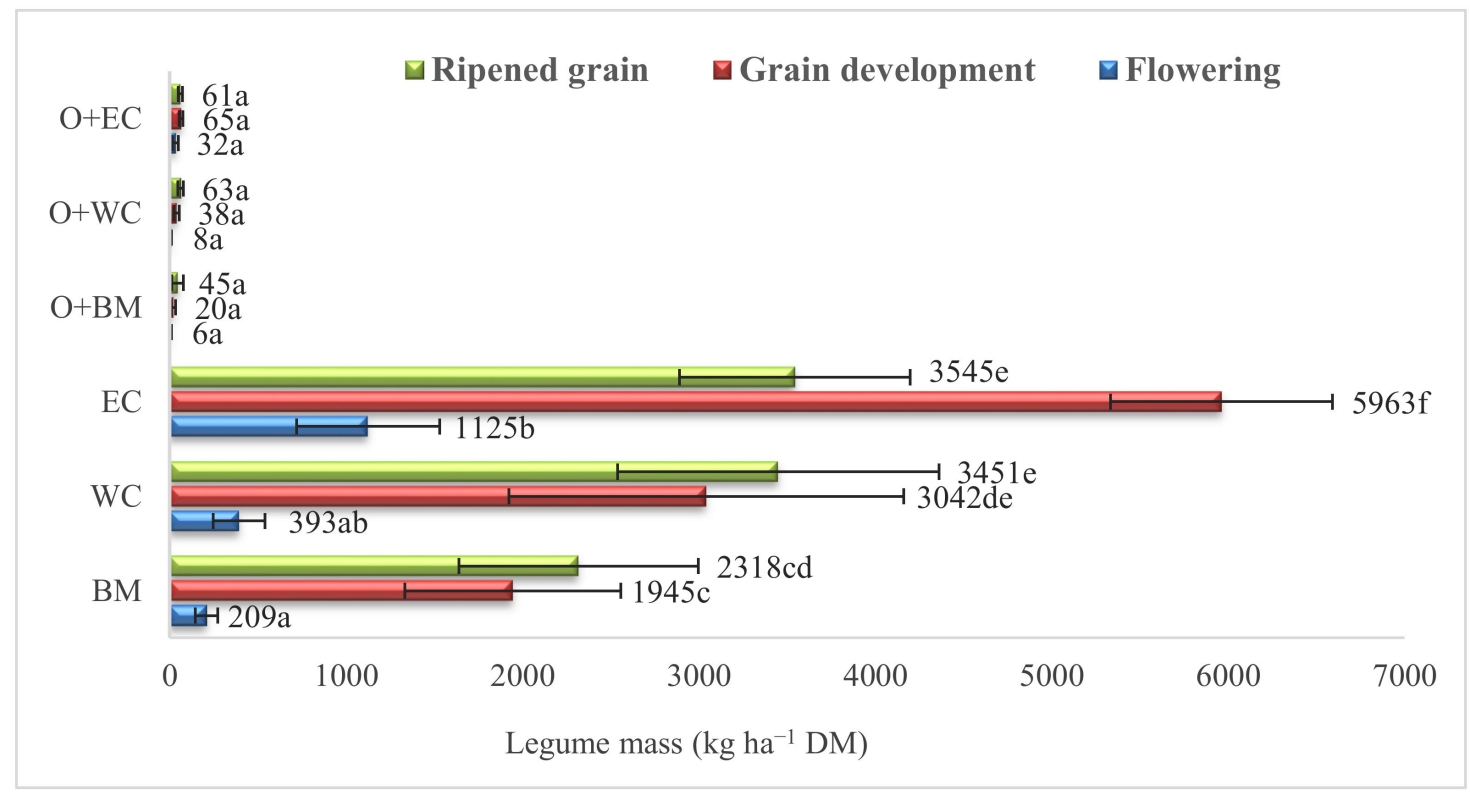

(b)

Figure 2. Forage legume aboveground mass during oat reproductive periods in 2018 (a) and 2019 (b). BM—black medick, WC-white clover, EC-Egyptian clover; intercropping systems: $\mathrm{O}+\mathrm{BM}$ - oat-black medick, $\mathrm{O}+\mathrm{WC}$-oat-white clover, $\mathrm{O}+\mathrm{EC}-\mathrm{oat}-\mathrm{Egyptian}$ clover; means followed by the same letters are not significantly different at $p \leq 0.05$.

\subsection{Oat and Forage Legume Competition}

Competitive oat $\left(\mathrm{CP}_{\mathrm{o}}\right)$ results in the oat-forage legume relay intercrop were expressed as a percentage decrease in the aboveground mass of forage legume (Table 3). The competi- 
tive performance was significantly $(p<0.01)$ influenced by year. The relay intercropping systems assessment time did not have any significant effect on this indicator. In all assessment time, a strong decrease (91.4-98.9\%) in the aboveground mass of forage legumes was found. On average, in 2019, the CP value was significantly 2.5 percentage points lower than in 2018. Plant competition in relay intercrop depended on the influence of meteorological conditions on the parallel germination and growth of oats and forage legumes.

Table 3. Competitive performance $\left(\mathrm{CP}_{\mathrm{O}} \%\right)$ of oats in oat-forage legume relay intercropping (mean \pm ).

\begin{tabular}{ccccccc}
\hline \multirow{2}{*}{ Intercrop } & \multicolumn{3}{c}{$\mathbf{2 0 1 8}$} & \multicolumn{2}{c}{$\mathbf{2 0 1 9}$} \\
\cline { 2 - 7 } & \multicolumn{3}{c}{ Oat Reproductive Stage } & \multicolumn{3}{c}{ Oat Reproductive Stage } \\
\cline { 2 - 7 } & Flowering & Grain Development & Ripened Grain & Flowering & Grain Development & Ripened Grain \\
\hline O+BM & $97.1 \pm 1.31$ & $98.9 \pm 0.47$ & $98.0 \pm 0.81$ & $96.3 \pm 2.89$ & $91.4 \pm 3.17$ & $97.7 \pm 0.53$ \\
\hline O+WC & $97.7 \pm 0.67$ & $98.5 \pm 057$ & $98.1 \pm 0.28$ & $96.2 \pm 2.98$ & $97.5 \pm 2.08$ & $95.7 \pm 2.11$ \\
\hline O+EC & $97.0 \pm 1.07$ & $98.9 \pm 0.17$ & $98.2 \pm 0.34$ & $95.9 \pm 2.33$ & $92.5 \pm 3.95$ & $97.0 \pm 0.65$ \\
\hline Mean of year & & & $98.1 \mathrm{a}$ & & & \\
\hline
\end{tabular}

Intercropping systems: $\mathrm{O}+\mathrm{BM}$-oat-black medick, $\mathrm{O}+\mathrm{WC}$-oat-white clover, $\mathrm{O}+\mathrm{EC}$-oat-Egyptian clover; means followed by the same letters are not significantly different at $p \leq 0.01$.

The growth intensity of the aboveground mass of forage legumes varied from year to year (Figure 3). Forage legumes grew most intensively in the following oat growth stages: in 2018 (BBCH 61-73), and in 2019 (BBCH 71-89). This did not affect the legume yield. The growth of legumes was influenced not only by oat productivity (competition), but also by favourable environmental conditions. Under favourable conditions, the legumes easily adapted to the growth rhythm and intensity of oats. In extensive intercultural systems, the yield of legumes is low and the main growth takes place after the oats are harvested.

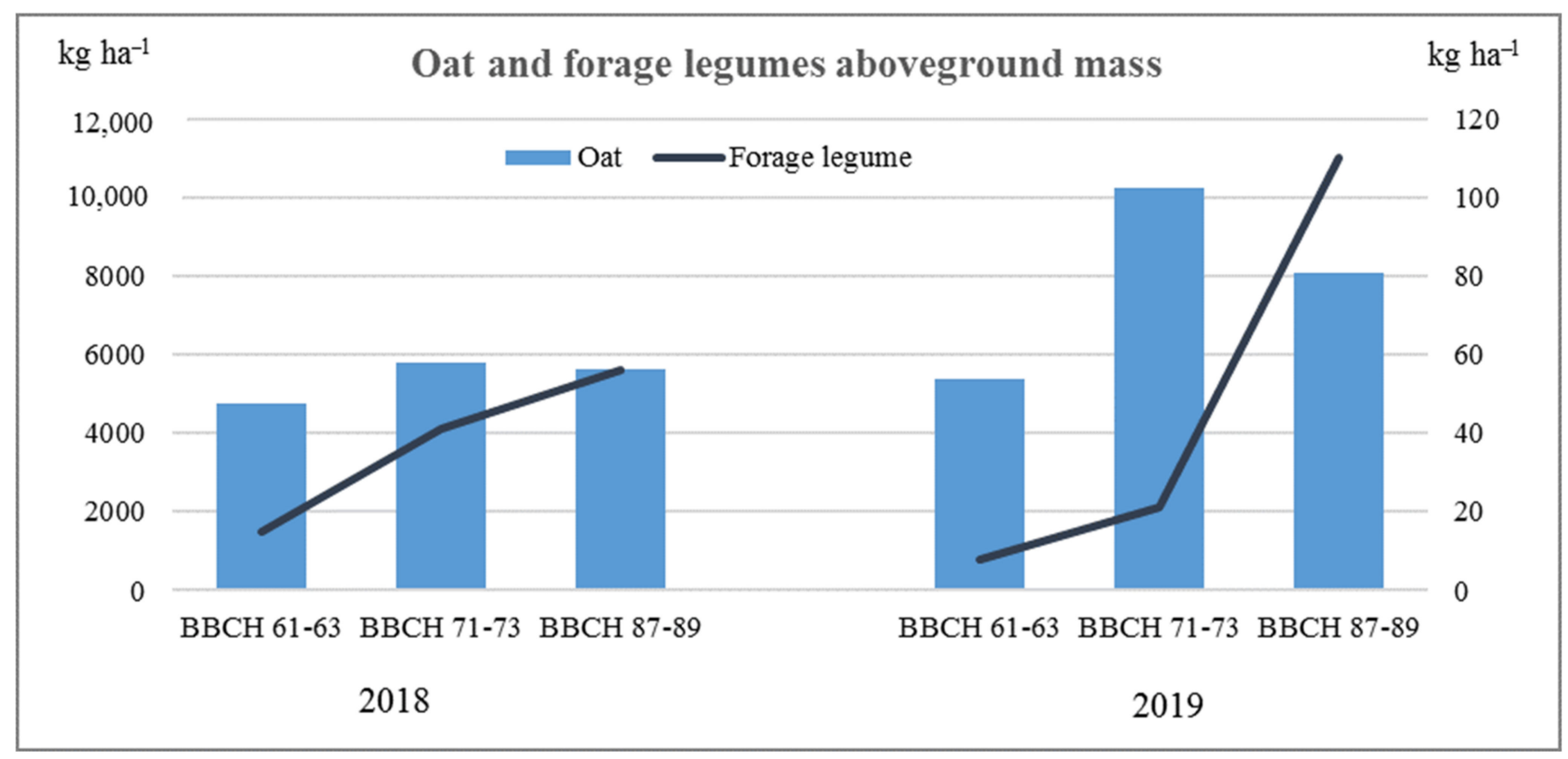

Figure 3. Dynamics of oat and forage legume aboveground mass change during the vegetation period in intercropping systems (average data). Oats growth stages: (BBCH 61-63) flowering, (BBCH 71-73) grain development, (BBCH 87-89) ripened grain. 


\subsection{Weeds Mass}

Statistical analysis results showed that the legume aboveground mass yields were influenced by the interaction of all three factors (year, assessment time and treatment, Table 1). During oat flowering the greatest weed mass was found in all types of forage legume sole crops (Figure 4). During grain development, the weed mass increased 4.5 and 1.3 times (in 2018 and 2019, respectively) compared to the flowering stage. In both years, a significantly greater weed mass was found in legume monocrops, being inversely proportional to the legume mass. The greatest weed mass was found in the BM monocrop. In oat-forage legume intercropping systems the mass of weeds was significantly lower compared to the legume monocrops.

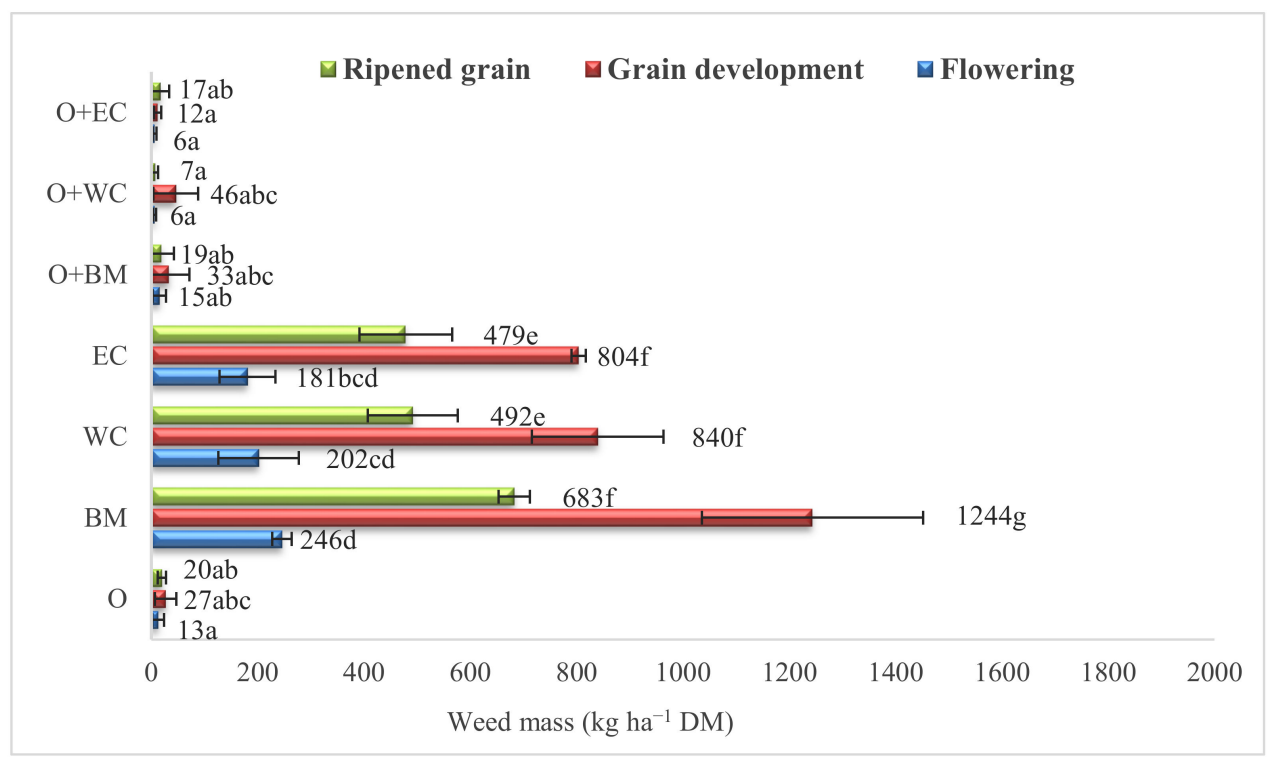

(a)

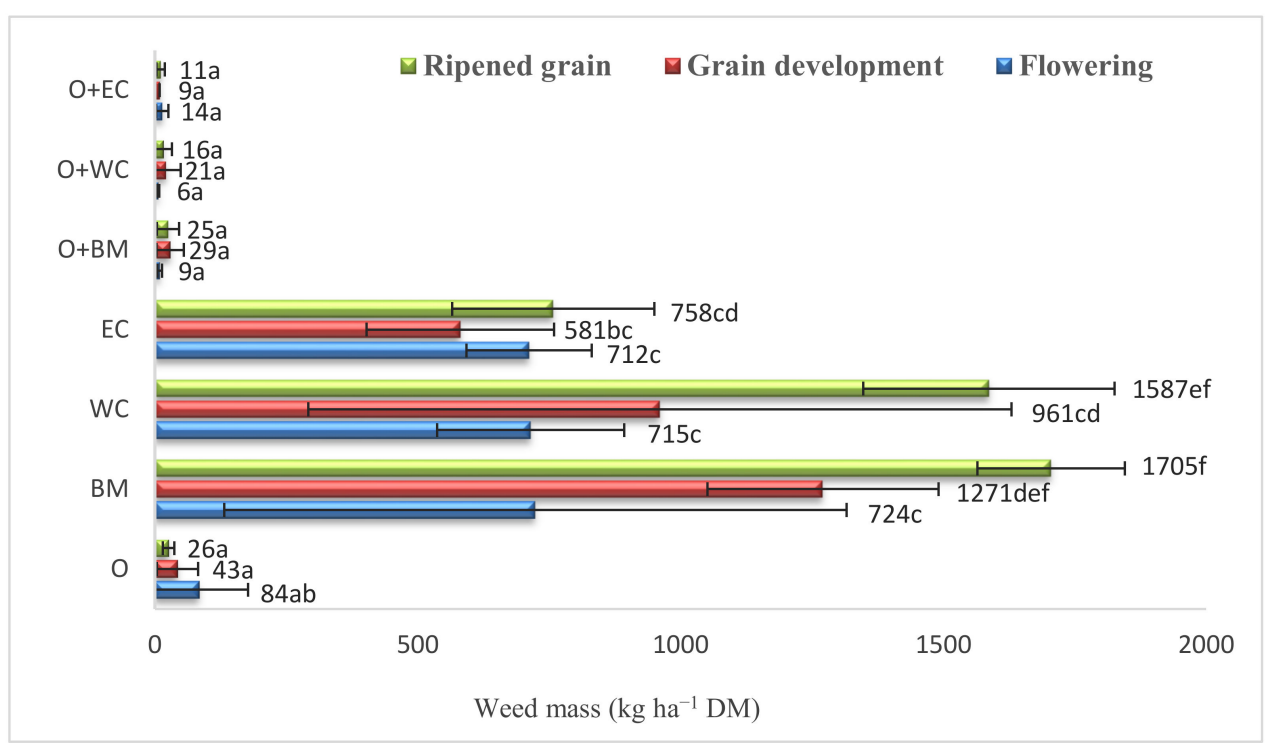

(b)

Figure 4. Weed aboveground mass during oat reproductive periods in 2018 (a) and 2019 (b).BMblack medick, WC-white clover, EC—Egyptian clover; intercropping systems: O+BM—oat-black medick, O+WC—oat-white clover, $\mathrm{O}+\mathrm{EC}-$ oat-Egyptian clover; means followed by the same letters are not significantly different at $p \leq 0.05$. 
In 2018, weed mass decreased compared to the second record (ripened grain). Significantly higher weed mass was found in legume monocrops and depended on the yield of aboveground mass of legumes. Meanwhile, the weed mass in 2019 varied less consistently. The increase in weed mass was greatest in legume monocrops. In both years, the weed mass decreased most in the oat monocrop and in $\mathrm{O}+\mathrm{BM}$ and $\mathrm{O}+\mathrm{WC}$ relay intercropping systems (compared to the second record). Hereupon, the weed mass tended to increase in growing oats intercropped with annual EC, compared to the second record. This species of annual clover matures earliest and exposes the soil surface, thus creating favourable conditions for weeds to grow.

According to the data from both study years, significant competitive relationships between the bottom level plants (legumes and weeds) and oat in intercropping systems were established at the beginning of oat reproduction. A moderate inverse linear relationship was obtained between the aboveground mass of oats and the mass of lower-level plants (forage legumes and weeds) (Figure 5). There were no consistent relationships during oat maturation. In intercropping systems, the correlations of weed aboveground mass with forage legume mass were weak and nonsignificant at all measurement dates.

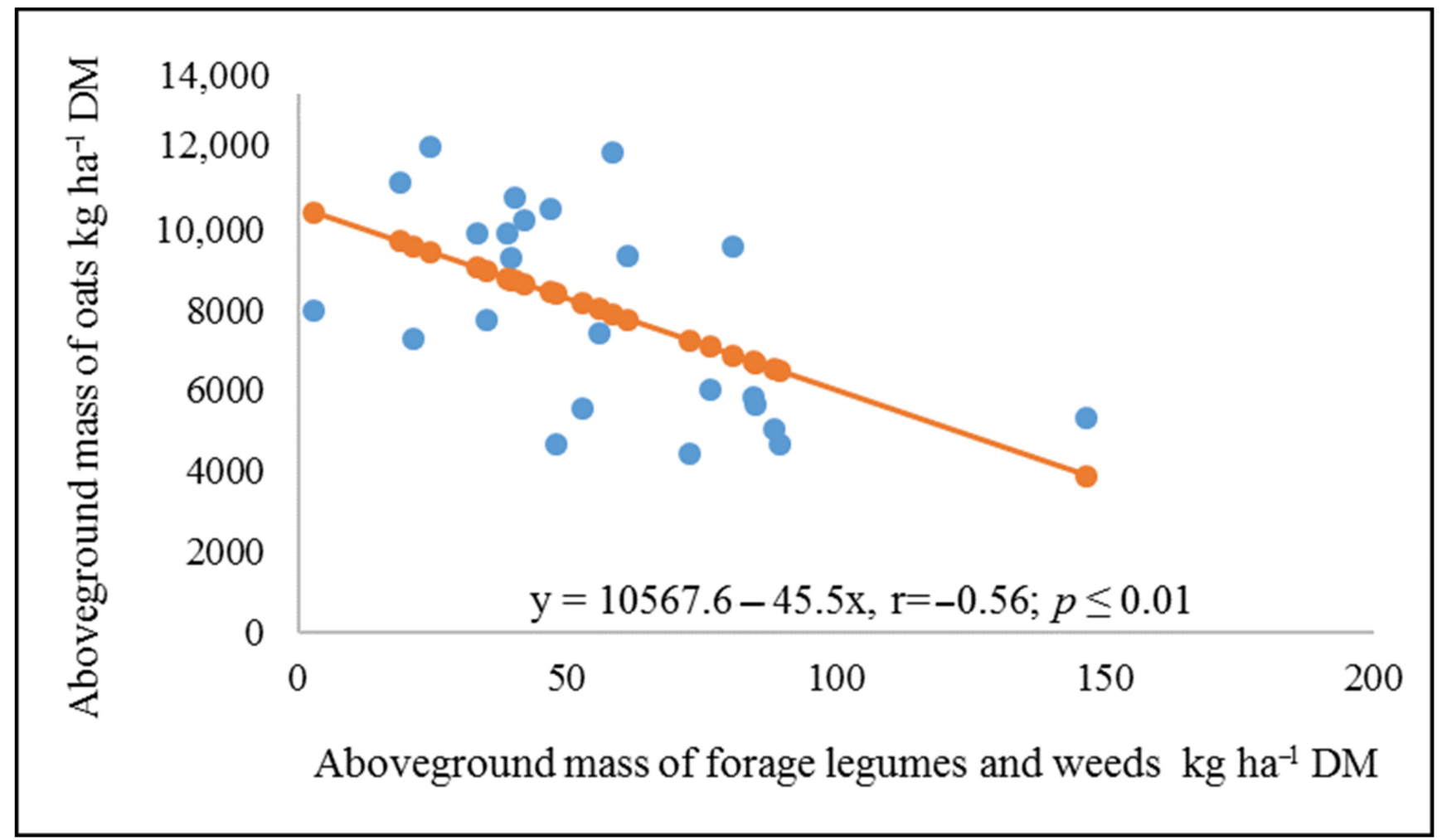

Figure 5. Dependence of aboveground mass yield of oats (grain development stage) on the total aboveground mass of forage legumes and weeds in oats-forage legume intercropping systems.

\subsection{Oat Grain Yield and Its Components}

Our results showed that the yield and its components were most affected by the meteorological conditions of the years. The influence of the forage legumes was not significant. Having compared the data for different growth periods it was found that the number of plants and panicles in 2019 was lower, and the number and weight of grains per panicle and TGW were higher compared to the data for 2018 (Table 4). 
Table 4. The variation in grain yield components of oat growing with or without forage legumes.

\begin{tabular}{|c|c|c|c|c|c|c|c|}
\hline \multirow{2}{*}{$\begin{array}{l}\text { Mono- and } \\
\text { Intercrops }\end{array}$} & \multicolumn{2}{|c|}{$\begin{array}{l}\text { Crop Number } \\
\text { (Plant } \mathrm{m}^{-2} \text { ) }\end{array}$} & \multirow{2}{*}{$\begin{array}{c}\text { Number of } \\
\text { Panicles } \\
\left(\text { Panicle } \mathbf{m}^{-2} \text { ) }\right.\end{array}$} & \multirow{2}{*}{$\begin{array}{c}\text { Grain Number } \\
\text { per Panicle }\end{array}$} & \multirow{2}{*}{$\begin{array}{l}\text { Grain Weight } \\
\text { per Panicle g }\end{array}$} & \multirow[t]{2}{*}{ TGW g } & \multirow{2}{*}{$\begin{array}{l}\text { Grain Yield } \\
\mathrm{Kg} \mathrm{ha}^{-1}\end{array}$} \\
\hline & Forage Legumes & Oats & & & & & \\
\hline \multicolumn{8}{|c|}{2018} \\
\hline $\mathrm{O}$ & & 411 & 418 & 44.3 & 1.46 & 32.3 & $2889 a b$ \\
\hline $\mathrm{O}+\mathrm{BM}$ & 33 & 408 & 445 & 34.3 & 1.11 & 32.9 & $2900 \mathrm{ab}$ \\
\hline $\mathrm{O}+\mathrm{WC}$ & 32 & 413 & 425 & 37 & 1.16 & 32.9 & $2932 a b$ \\
\hline $\mathrm{O}+\mathrm{EC}$ & 29 & 396 & 451 & 36 & 1.15 & 32.7 & $3058 \mathrm{~b}$ \\
\hline Mean & $31 \mathrm{a}$ & $407 \mathrm{~b}$ & $434 \mathrm{~b}$ & $37.9 \mathrm{a}$ & $1.22 \mathrm{a}$ & $32.7 \mathrm{a}$ & 2945 \\
\hline \multicolumn{8}{|c|}{2019} \\
\hline $\mathrm{O}$ & & 339 & 371 & 55 & 1.99 & 38.1 & $4087 \mathrm{~b}$ \\
\hline $\mathrm{O}+\mathrm{BM}$ & 38 & 334 & 380 & 57 & 2.01 & 38.5 & $4075 \mathrm{ab}$ \\
\hline $\mathrm{O}+\mathrm{WC}$ & 42 & 328 & 382 & 55 & 2.02 & 39.2 & $3974 \mathrm{ab}$ \\
\hline $\mathrm{O}+\mathrm{EC}$ & 49 & 329 & 348 & 57 & 2.02 & 38.9 & $3892 \mathrm{ab}$ \\
\hline Mean & $43 b$ & $333 a$ & $370 \mathrm{a}$ & $55.8 \mathrm{~b}$ & $2.01 \mathrm{~b}$ & $38.7 \mathrm{~b}$ & 4007 \\
\hline
\end{tabular}

$\mathrm{O}$-oat, BM—black medick, WC—white clover, EC—Egyptian clover; intercrop systems: O+BM-oat-black medick, O+WC—oat-white clover, O+EC—oat-Egyptian clover; means followed by the same letters are not significantly different at $p \leq 0.05$.

This was due to meteorological conditions in 2019 (Figure 1a). As far as legume and oat intercropping was concerned, in 2018, the number and weight of grains per oat panicle were significantly reduced compared to oat monocropping. In 2019, less favourable plant germination conditions led to a thinner oat crop and less consistent productivity indicators. Productivity rates of oat panicles were significantly higher in the thinner crop compared to 2018. There was no significant difference between treatments. The change in yield was due to the different distribution of productivity indicators.

\subsection{Nutrient Content in Oat Grain and Legume Biomass}

Oat grains were accumulated $15.0-15.80$ and $20.79-21.54 \mathrm{~g} \mathrm{~N} \mathrm{~kg}^{-1} \mathrm{DM}, 3.29-3.64$ and 3.12-3.33 $\mathrm{g} \mathrm{P} \mathrm{kg}^{-1} \mathrm{DM}$ in 6.62-7.09 and 3.04-3.30 $\mathrm{g} \mathrm{K} \mathrm{kg}^{-1} \mathrm{DM}$ in 2018 and 2019, respectively. Concentration of nutrients (NK) in grains depended on the year $(p<0.01)$, legumes had no significant effect. The amount of nutrients accumulated in the oats grain was influenced by the yield. Intercropping of forage legumes with oats and annual conditions influenced the content of nutrients accumulated in grain. In 2019, the N concentration in grain was $38.7 \%$ higher on average, and nitrogen content accumulated in the yield was nearly two times higher compared to 2018. Due to the influence of the year, phosphorus concentration in oat grain varied slightly. In 2018, significantly more potassium was used to grow $1 \mathrm{~kg}$ of oat grain compared to 2019. These study data indicated a tendency for annual $\mathrm{O}+\mathrm{EC}$ intercropping systems to increase competition with oats for nutrients, in contrast to perennial forage legumes.

More pronounced differences in NPK concentrations were found in the aboveground mass of forage legumes (Table 5). In 2018, significantly lesser nitrogen concentrations were found in the EC mass when intercropped with oats compared to other forage legume species, regardless of their cultivation method (in mono- and intercropping). In 2019, a significantly higher concentration in the WC aboveground mass was found in the $\mathrm{O}+\mathrm{WC}$ relay intercrop compared to the monocrop. The greatest aboveground mass $\mathrm{P}$ concentration was measured in EC (2018) and BM (2019), regardless of the cultivation method. Correlation analysis showed that with increasing $\mathrm{P}$ concentration in grain of oat, its value in aboveground mass of forage legume decreased as well (Figure 6). The most adverse effects were found for EC. In 2019, favourable for plant growth, this relationship was nonsignificant $(\mathrm{r}=-0.49)$. 
Table 5. Amount of nutrients accumulated in aboveground mass of forage legumes.

\begin{tabular}{|c|c|c|c|c|c|c|}
\hline \multirow{2}{*}{ Treatment } & \multicolumn{3}{|c|}{ Concentration of Nutrients, $\mathrm{g} \mathrm{kg}^{-1} \mathrm{DM}$} & \multicolumn{3}{|c|}{ Accumulated Nutrients, $\mathrm{kg} \mathrm{ha}^{-1} \mathrm{DM}$} \\
\hline & $\mathbf{N}$ & $\mathbf{P}$ & K & $\mathbf{N}$ & $\mathbf{P}$ & $\mathbf{K}$ \\
\hline \multicolumn{7}{|c|}{2018} \\
\hline $\mathrm{BM}$ & $28.10 \mathrm{bc}$ & $2.84 \mathrm{ab}$ & $22.77 \mathrm{ab}$ & 65.13 & 6.58 & 52.32 \\
\hline WC & 28.87 bcde & $2.95 \mathrm{ab}$ & $32.40 \mathrm{~cd}$ & 117.01 & 10.22 & 111.48 \\
\hline EC & $28.50 \mathrm{bc}$ & $3.29 \mathrm{~d}$ & $30.37 \mathrm{c}$ & 100.72 & 11.65 & 106.32 \\
\hline $\mathrm{O}+\mathrm{BM}$ & $27.80 \mathrm{~b}$ & $2.99 \mathrm{abcd}$ & 40.17 def & 1.33 & 0.14 & 1.60 \\
\hline $\mathrm{O}+\mathrm{WC}$ & $27.83 \mathrm{~b}$ & $2.98 \mathrm{ab}$ & $41.27 \mathrm{f}$ & 1.75 & 0.19 & 2.61 \\
\hline $\mathrm{O}+\mathrm{EC}$ & $22.20 \mathrm{a}$ & $3.29 \mathrm{~cd}$ & $\begin{array}{c}33.87 \text { cdef } \\
2019\end{array}$ & 1.36 & 0.20 & 2.06 \\
\hline $\mathrm{BM}$ & 30.9 bcde & $2.97 \mathrm{ab}$ & $27.93 \mathrm{bc}$ & 82.51 & 7.95 & 74.51 \\
\hline WC & 28.87 bcde & $2.75 \mathrm{a}$ & 34.13 cdef & 96.36 & 8.84 & 110.63 \\
\hline $\mathrm{EC}$ & 29.63 bcde & $2.88 \mathrm{ab}$ & $26.90 \mathrm{abc}$ & 115.74 & 11.25 & 105.12 \\
\hline $\mathrm{O}+\mathrm{BM}$ & 31.75 cde & $3.10 \mathrm{bcd}$ & $20.93 \mathrm{a}$ & 2.09 & 0.20 & 1.33 \\
\hline $\mathrm{O}+\mathrm{WC}$ & $32.68 \mathrm{e}$ & $2.88 \mathrm{ab}$ & $31.68 \mathrm{c}$ & 4.86 & 0.43 & 4.56 \\
\hline $\mathrm{O}+\mathrm{EC}$ & 29.63 bcde & $2.88 \mathrm{ab}$ & $26.90 \mathrm{abc}$ & 3.63 & 0.35 & 3.31 \\
\hline \multicolumn{7}{|c|}{ Mean of I c } \\
\hline $\mathrm{BM}$ & & & & $73.82 \mathrm{~d}$ & $7.26 \mathrm{~b}$ & $63.41 \mathrm{~b}$ \\
\hline WC & & & & $106.69 \mathrm{c}$ & $9.53 c$ & 105.72 c \\
\hline $\mathrm{EC}$ & & & & $108.23 \mathrm{c}$ & $11.45 \mathrm{~d}$ & $111.05 \mathrm{c}$ \\
\hline $\mathrm{O}+\mathrm{BM}$ & & & & $1.71 \mathrm{a}$ & $0.17 \mathrm{a}$ & $1.47 \mathrm{a}$ \\
\hline $\mathrm{O}+\mathrm{WC}$ & & & & $3.3 \mathrm{a}$ & $0.31 \mathrm{a}$ & $3.59 \mathrm{a}$ \\
\hline $\mathrm{O}+\mathrm{EC}$ & & & & $2.50 \mathrm{a}$ & $0.28 \mathrm{a}$ & $2.69 \mathrm{a}$ \\
\hline
\end{tabular}

BM-black medick, WC—white clover, EC—Egyptian clover; intercrop systems: O+BM-oat-black medick, O+WC—oat-white clover, $\mathrm{O}+\mathrm{EC}$-oat-Egyptian clover; $\mathrm{N}-$ nitrogen, $\mathrm{P}$-phosphorus, $\mathrm{K}$-potassium; means followed by the same letters are not significantly different at $p \leq 0.05$.

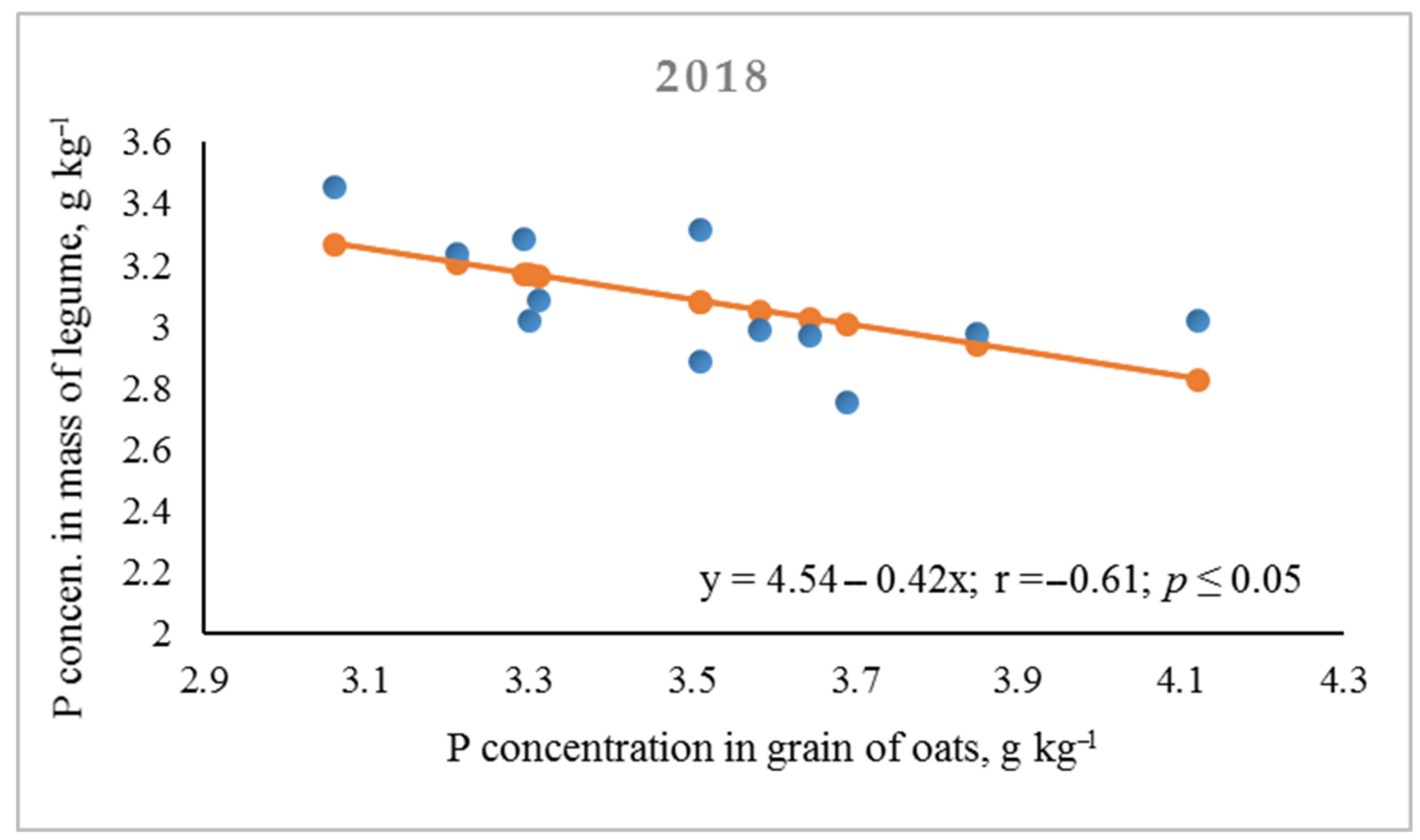

Figure 6. Dependence of $\mathrm{P}$ in grain yield of oat (ripened grain stage) on the $\mathrm{P}$ of aboveground mass of forage legume in intercropping systems. 
The highest potassium concentration was found in the WC biomass, regardless of the year and cultivation method. Black medick grown in monocrop (2018 and intercrop (2019) also EC (regardless of their cultivation method in 2019) had significantly less concentration of $\mathrm{K}$ in aboveground mass.

The significant influence of forage legume cultivation methods (in mono- and intercrop) on nutrient accumulation in aboveground mass has been identified $(p<0.01)$. Having compared different legume monocultures, BM was found to have accumulated the lowest nitrogen amount in the aboveground mass. Forage legumes intercropped with oats demonstrated low nitrogen accumulation (1.33-1.75 kg ha ${ }^{-1} \mathrm{DM}$ in 2018 on average, and $2.09-4.86 \mathrm{~kg} \mathrm{ha}^{-1}$ in 2019), there was no significant difference between legume species. A very low phosphorus amount was accumulated in the legume mass in relay intercropping systems. WC and EC, grown as monocrops, demonstrated higher phosphorus content in biomass. Of the forage legumes grown in monoculture, BM accumulated the lowest levels of potassium (as well as nitrogen and phosphorus), and WC accumulated the highest ones. Similarly, the potassium content varied in the aboveground mass of other forage legumes intercropped with oats.

\section{Discussion}

Oats held the dominant position in oat-forage legume relay intercropping systems. The regularities of oat yield formation were determined by meteorological conditions and self-regulatory functions of crop productivity. In 2019, underdeveloped reproductive stems were compensated by a higher number of grains and their weight compared to a denser 2018 crop. Our studies suggest that the forage legume in relay intercropping systems may have a negative effect on later-emerging crop components (grain number and weight); nevertheless, it did not reduce yield. The data are consistent with those of other researchers who argue that legumes in relay intercropping systems have no significant effect on cereal yield [8]. According to Gaudin et al. [11] red clover can compete with cereals and even reduce their yield.

Studies of the dynamics of oat aboveground mass accumulation showed that the accumulation of DM took place most intensively in 2019 and continued even after the flowering of cereals. This year was characterised by cool weather and sufficient rainfall. The period from flowering to the beginning of maturity, when there is enough moisture, nutrients and maximum amount of solar energy, is of great importance for plant productivity [27]. During oat maturation (mid-July to early August), the redistribution of accumulated assimilated materials in plants resulted in a decrease (2019) or a marginal variation (2018) in the aboveground mass of oats. A number of researchers have observed a decline in cereal competition at the end of the plant growth period [7]. During this period, favourable conditions are created for the plants of the lower crop level to grow. It is argued that the dominance of cereals over forage legumes is necessary to avoid cereal yield losses [28].

In relay intercrops, the aboveground mass of forage legumes began to form more intensively after heading of oats. Annual EC developed most intensively, demonstrating the highest mass. A previous study [7] indicated that the highest competition between spring wheat and annual Persian clover (Trifolium resupinatum L.) occurs when cereals are in the stem elongation stage (BBCH 31-32); the mass of annual clover decreases twice during the entire growth period. Contrary to Barilli et al. [10] and Sharpe et al. [24] the aboveground mass of BM was the lowest in intercrop. This may have been determined by the genetic diversity of the species and varietal characteristics. According to other researchers, BM and red clover competed best with winter wheat, in contrast to BM and WC [8]. Our studies concur with Bybee-Finley and Ryan [5] that the accumulation of forage legume mass in a cereal crop is minimal and most of the biomass is formed after cereal harvest. It is believed that forage legume mass increases six times during the postharvest period [29]. Environmental variables such as soil type, precipitation quantity and distribution during the growing season and day length also have an effect on biomass accumulation [11]. Fertile clay loam soils have a higher supply of resources and lower 
competition between plants compared to less fertile ones, where oats are usually grown. Clover is considered to be an under sown crop that poorly competes with cereals [30]. Our study substantiated this argument. In relay intercrops, WC, BM and EC were dominated by oats for all growing periods.

Under sown forage legumes establish in the lower crop level and compete with weeds. This is especially important in the second half of summer when an under sown clover with drying crop leaves covers the soil surface [11]. Plants and weeds compete for light, water and nutrient resources [31,32]. Den Hollander et al. [33] state that the relative growth rate is determined by the characteristics of clover, such as light extinction coefficient, light use efficiency and specific leaf area. It was determined that the fastest soil surface cover was demonstrated by Persian clover. [11] reported that forage legume species that produce a high yield of aboveground mass are considered to be effective competitors for local resources. The competitive properties of forage legumes also depend on the sowing rate and sowing time. Forage legumes under sown in cereals can suppress weeds, however, legumes can compete with cereals too [33]. Verret et al. [34] indicated that the use of legume companion plants generally seemed to enhance weed control without reducing crop yield. Our research shows that oat was the most weed suppressive, and the forage legumes in relay intercropping systems only enhanced their effect as oats matured. Egyptian clover competed best with weeds, as confirmed by other researchers [35]. The positive effect of low-mass forage legumes on weed reduction cannot be assessed unequivocally. Many weed species are adapted to spread in cereal crops. Therefore, as cereals mature and forage legumes grow intensively, some of the weeds have already matured their seeds and dried out.

In our studies, forage legumes accumulated low $\mathrm{N}$, which is confirmed by other researchers [30]. A decrease in light and water resources under the cereal canopy may also directly reduce nodule formation and N fixation in clover species [36]. On the other hand, forage legumes that are intercropped with cereal also fix a greater proportion of nitrogen than legumes grown in monoculture [13]. Nitrogen uptake in under sown crops is affected by competition with main crops [37]. It is proposed that the competition for $\mathrm{N}$ can be detrimental when cereals and legume catch crops are sown simultaneously in spring [8]. Additionally, catch crops generally seem more suitable as post crops for P [38]. Plant species with different growth cycles can ensure a more efficient use of environmental resources. We can say that, in our studies, the drought after sowing postponed the competition for resources between the intercropped plants and oats. Forage legumes, that produced a small aboveground mass, accumulated low $\mathrm{N}$ levels, which is confirmed by other researchers. Our research has shown that EC with a growth period similar to oats can compete more intensively with oat for resources. Meanwhile, the intensity of WC and BM nutrient uptake increased with maturation of oats and the decrease in nutrient utilisation by the oat. The high yield of intercropping is connected to better exploitation of soil resources, and deep rooting of some species is a determinant factor for complementarity in competition for soil resources [9]. They may also have the ability to absorb different quantities of nutrients and produce distinct root exudates (organic acids) resulting in benefits both for the soil and organisms [10]. Finally, one crop can provide resources for the other one with a positive interspecific interaction, which is at the basis of facilitation processes [10].

\section{Conclusions}

Oats dominated in oat-forage legume relay intercropping systems. Meteorological conditions of the year and crop self-regulation functions had a significant impact on the yield components of oats and the regularities of aboveground mass formation. This determined the intensity of aboveground mass formation of forage legumes in relay intercrop. Forage legumes grew most intensively in the following oat growth stages: In 2018 (BBCH 61-73), and in 2019 (BBCH 71-89). Annual EC demonstrated the earliest aboveground mass formation. Oat competitive performance $\left(\mathrm{CP}_{\mathrm{o}}\right)$, which is characterised by forage legumes aboveground mass reduction compared to monocrops, were $91.4-98.9 \%$. As the 
oats ripened, its competitiveness tended to decline. In oat-forage legume intercropping systems, the mass of weeds was significantly lower, compared to the legume monocrops. The total mass of forage legumes and weeds during their period of intensive growth was negatively correlated with the aboveground mass yield of oats (BBCH 71-73). Oats and forage legumes competed for $\mathrm{P}$, but $\mathrm{N}$ and $\mathrm{K}$ accumulation in biomass was not significantly affected Legumes in intercrops accumulated a small amount of nutrients (N: $1.33-4.86 \mathrm{~kg}$ $\mathrm{ha}^{-1} \mathrm{DM}$; P: $0.14-0.43 \mathrm{~kg} \mathrm{ha}^{-1} \mathrm{DM}$ and $\left.\mathrm{K}: 1.33-4.56 \mathrm{~kg} \mathrm{ha}^{-1} \mathrm{DM}\right)$. The yield of forage legumes, as service crop, and amount of nutrients stored were still insufficient and must be left to grow in autumn.

Author Contributions: Conceptualization, V.G. and A.A.; methodology, A.A.; software, V.G. and A.A.; validation, V.G., A.A. and J.C.; formal analysis, A.A.; J.C.; investigation, V.G. and A.A.; resources, V.G.; J.C.; data curation, A.A.; writing—original draft preparation, V.G.; A.A.; J.C.; writing-review and editing, V.G.; A.A. and J.C.; visualization, A.A.; supervision, V.G.; project administration, funding acquisition. All authors have read and agreed to the published version of the manuscript.

Funding: This research received no external funding.

Data Availability Statement: Our institution does not have a data collection database.

Acknowledgments: This research was part of the long-term programme 'Biopotential and quality of plants for multifunctional use' implemented by the Lithuanian Research Centre for Agriculture and Forestry. We also acknowledge the support provided by all technical personnel for fieldwork and laboratory analyses.

Conflicts of Interest: The authors declare no conflict of interest.

\section{References}

1. Bedoussac, L.; Journet, E.-P.; Hauggaard-Nielsen, H.; Naudin, C.; Corre-Hellou, G.; Jensen, E.S.; Prieur, L.; Justes, E. Ecological principles underlying the increase of productivity achieved by cereal-grain legume intercrops in organic farming. A review. Agron. Sustain. Dev. 2015, 35, 911-935. [CrossRef]

2. Brooker, R.W.; Bennett, A.E.; Cong, W.F.; Daniell, T.J.; George, T.S.; Hallett, P.D.; Hawes, C.; Iannetta, P.P.M.; Jones, H.G.; Karley, A.J.; et al. Improving intercropping: A synthesis of research in agronomy, plant physiology and ecology. New Phytol. 2014, 206, 107-117. [CrossRef] [PubMed]

3. Willey, R.W. Intercropping-Its importance and research needs. Part 1. Competition and yield advantages. F. Crop. Res. 1979, 32, 1-10.

4. Hauggaard-Nielsen, H.; Jørnsgaard, B.; Kinane, J.; Jensen, E.S. Grain legume-cereal intercropping: The practical application of diversity, competition and facilitation in arable and organic cropping systems. Renew. Agric. Food Syst. 2008, 23, 3-12. [CrossRef]

5. Bybee-Finley, K.A.; Ryan, M.R. Advancing Intercropping Research and Practices in Industrialized Agricultural Landscapes. Agriculture 2018, 8, 80. [CrossRef]

6. Wyngaarden, S.L.; Gaudin, A.C.M.; Deen, W.; Martin, R.C. Expanding Red Clover (Trifolium pratense) Usage in the Corn-SoyWheat Rotation. Sustainability 2015, 7, 15487-15509. [CrossRef]

7. Wanic, M.; Mysliwiec, M.; Orzech, K.; Michalska, M. Nitrogen content and uptake by spring wheat and undersown Persian clover depending on plant density. J. Elem. 2016, 21, 231-246. [CrossRef]

8. Amossé, C.; Jeuffroy, M.-H.; Mary, B.; David, C. Contribution of relay intercropping with legume cover crops on nitrogen dynamics in organic grain systems. Nutr. Cycl. Agroecosyst. 2014, 98. [CrossRef]

9. Hassan, A.; Dresbøll, D.B.; Rasmussen, C.R.; Lyhne-Kjærbye, A.; Nicolaisen, M.H.; Stokholm, M.S.; Lund, O.S.; Thorup-Kristensen, K. Root distribution in intercropping systems-A comparison of DNA based methods and visual distinction of roots. Arch. Agron. Soil Sci. 2019, 2, 1476-3567. [CrossRef]

10. Barilli, E.; Jeuffroy, M.H.; Gall, J.; Tourdonnet, S.; Médiène, S. Weed response and crop growth in winter wheat-lucerne intercropping: A comparison of conventional and reduced soil-tillage conditions in northern France. Crop. Pasture Sci. 2017, 68, 1070-1079. [CrossRef]

11. Gaudin, A.C.M.; Westra, S.; Loucks, C.E.S.; Janovicek, K.; Martin, R.; Deen, B. Improving Resilience of Northern Field Crop Systems Using Inter-Seeded Red Clover: A Review. Agron. J. 2013, 3, 148-180. [CrossRef]

12. Arlauskienè, A.; Cesevičienè, J.; Velykis, A. Improving mineral nitrogen control by combining catch crops, fertilisation, and straw management in a clay loam soil. Acta Agric. Scand. B Soil Plant Sci. 2019, 69, 422-431. [CrossRef]

13. Schipanski, M.E.; Drinkwater, L.E. Nitrogen fixation of red clover interseeded with winter cereals across a management-induced fertility gradient. Nutr. Cycle. Agroeco. 2011, 90, 105-119. [CrossRef]

14. Notaris, C.D.; Rasmussen, J.; Sørensen, P.; Melander, B.; Olesena, J.E. Manipulating cover crop growth by adjusting sowing time and cereal interrow spacing to enhance residual nitrogen effects. Field Crops Res. 2019, 234, 15-25. [CrossRef] 
15. Arlauskienè, A.; Maikštenienè, S.; Šarūnaitè, L.; Kadžiulienè, Ž.; Deveikytė, I.; Žèkaitè, V.; Česnulevičienè, R. Competitiveness and productivity of organically grown pea and spring cereal intercrops. Zemdirb. Agric. 2011, 98, 339-348.

16. Šarūnaitè, L.; Deveikytè, I.; Arlauskienè, A.; Kadžiulienè, Ž.; Maikštènienè, S. Pea and Spring Cereal Intercropping Systems: Advantages and Suppression of Broad-Leaved Weeds. Pol. J. Environ. Stud. 2013, 22, 541-551.

17. Kaur, A.; Kaur, K.P.; Kalia, A.; Rani, U.; Kahlon, J.G.; Sharma, R.; Malaviya, D.; Kapoor, R.; Sandhu, J.S. Generation of interspecific hybrids between Trifolium vesiculosumand T. alexandrinum using embryo rescue. Euphytica 2017, 253. [CrossRef]

18. Hannaway, D.B.; Larson, C. Berseem clover (Trifolium alexandrinum L.). In Species Selection Information System; Oregon State University: Corvallis, OR, USA, 2018.

19. Ismail, F.S.; Hassanen, S.A.A. Improvement of Egyptian Clover Yield and Quality by Using Bio and Organic Fertilizers in Newly Cultivated Saline Soil. J. Soil Sci. Agric. Eng. 2019, 10, 147-155. [CrossRef]

20. Boe, A.; Bortnem, R.; Johnson, P.J. Changes in weight and germinability of black medic seed over a growing season, with a new seed predator. Proc. S. Dak. Acad. Sci. 2016, 95, 105-117.

21. Amer, N.; Al Chami, Z.; Al Bitar, L.; Mondelli, D.; Dumontet, S. Evaluation of Atriplex halimus, Medicago lupulina, and Portulaca oleracea for phytoremediation of $\mathrm{Ni}, \mathrm{Pb}$, and Zn. Int. J. Phyto. 2013, 15, 498-512. [CrossRef]

22. Elsalahy, H.; Döring, T.; Bellingrath-Kimura, S.; Arends, D. Weed suppression in only-legume cover crop mixtures. Agron. J. 2019, 9, 648. [CrossRef]

23. Entz, M.H.; Thiessen Martens, J.R.; May, W.; Lafond, G.P. Black medic (Medicago lupulina) germplasm screening for use as a self-regenerating cover crop on the Canadian Prairies. Can. J. Plant. Sci. 2007, 87, 873-878. [CrossRef]

24. Sharpe, S.M.; Boyd, N.S.; Dittmar, P.J.; MacDonald, G.E. Control Recommendations for Black Medic (Medicago lupulina) Based on Growth and Development in Competition with Strawberry. Weed Sci. 2018, 66, 226-233. [CrossRef]

25. Döring, T.F.; Baddeley, J.A.; Brown, R.; Collins, R.; Crowley, O.; Cuttle, S.P.; Howlett, S.A.; Jones, H.E.; McCalman, H.; Pearce, B.D. Using Legume-Based Mixtures to Enhance the Nitrogen use Efficiency and Economic Viability of Cropping Systems; Project Report for DEFRA No. RD-3447; 2013.

26. Tarakanovas, P.; Raudonius, S. Agronominiu Tyrimu Duomenu Statistine Analize Taikant Kompiuterines Programas ANOVA, STAT, SPLIT-PLOT from the Package SELEKCIJA and IRRISTAT; Lithuanian University of Agriculture: Akademija, Lithuania, 2003 ; p. 58.

27. Finney, D.M.; White, C.M.; Kaye, J.P. Biomass production and carbon/nitrogen ratio influence ecosystem services from cover crop mixtures. Agron. J. 2016, 108, 39-52. [CrossRef]

28. Andersen, M.K.; Hauggaard-Nielsen, H.; Weiner, J.; Jensen, E.S. Competitive dynamics in two-component intercrops. J. App. Ecol. 2007, 44, 545-551. [CrossRef]

29. Bergkvist, G.; Stenberg, M.; Wetterlind, J.; Båth, B.; Elfstrand, S. Clover cover crops under-sown in winter wheat increase yield of subsequent spring barley-Effect of $\mathrm{N}$ dose and companion grass. Field Crop. Res. 2011, 120, 292-298. [CrossRef]

30. Raudonius, S. Application of statistics in plant and crop research: Important issues. Zemdirb. Agric. 2017, 104, 377-382. [CrossRef]

31. Teasdale, J.; Brandsæter, L.; Calegari, A.; Neto, F.S. Cover Crops and Weed Management. In Non-Chemical Weed Management: Principles, Concepts and Techology; Upadhyaya, M.K., Blackshaw, R.E., Eds.; CABI International: Oxfordshire, UK, 2007; pp. 49-64.

32. Amosse, C.; Jeuffroy, M.H.; Celette, F.; David, C. Relay-intercropped forage legumes help to control weeds in organic grain production. Eur. J. Agron. 2013, 49, 158-167. [CrossRef]

33. Den Hollander, N.G.; Bastiaans, L.; Kropff, M.J. Clover as a cover crop for weed suppression in an intercropping design: II. Competitive ability of several clover species. Eur. J. Agron. 2007, 26, 104-112. [CrossRef]

34. Verret, V.; Gardarin, A.; Pelzer, E.; Médiène, S.; Makowski, D.; Valantin-Morison, M. Can legume companion plants control weeds without decreasing crop yield? A meta-analysis. Field Crop. Res. 2017, 204, 158-168. [CrossRef]

35. Ross, S.M.; King, J.R.; O'Donovan, J.T.; Spaner, D. Forage potential of intercropping berseem clover with barley, oat, or triticale. Agron. J. 2004, 96, 1013-1020. [CrossRef]

36. Silsbury, J.H. $\mathrm{CO}_{2}$ exchange and dinitrogen fixation of subterrenean clover in response to light level. Plant Physiol. 1981, 67, 599-602. [CrossRef] [PubMed]

37. Doltra, J.; Olesen, J.E. The role of catch crops in the ecological intensification of spring cereals in organic farming under Nordic climate. Eur. J. Agron. 2013, 44, 98-108. [CrossRef]

38. Liu, J.; Bergkvist, G.; Uléna, B. Biomass production and phosphorus retention by catch crops on clayey soils in southern and central Sweden. Field Crop. Res. 2015, 171, 130-137. [CrossRef] 